\title{
Board Structure and Firm Performance: Evidence from State Owned Enterprises in Kenya
}

\author{
Mongeri Oruke $^{1^{*}}$ Cyrus Mwangi Iraya ${ }^{2} \quad$ Nixon Oluoch Omoro $^{2} \quad$ Luther Odhiambo Otieno $^{2}$ \\ 1 PhD Student School of Business, University of Nairobi, Kenya \\ 2.School of Business, University of Nairobi, Kenya
}

\begin{abstract}
The study examines the relationship between board structure and firm performance in the state owned enterprises in Kenya. Data was collected from 25 state owned enterprises in the commercial and manufacturing sector covering the period 2014 to 2016 . To establish the relationship between the variables the study employed panel data regression, with fixed and random effects. The study findings established that board size had a positive and significant effect on firm performance. In contrast board independence had negative and significant effect on firm performance. The study findings indicate that that large boards improved firm performance while board independence had a negative impact on firm performance. Results for control variables firm size and firm age were positive and statistically significant. The findings from this study contributes to literature in corporate governance in public sector where comparatively empirical evidence is limited. The findings will prove useful in guiding policy in corporate governance practices in the public sector in Kenya.
\end{abstract}

Keywords: Corporate governance, Board size, board independence, Firm Performance, State Owned enterprises. DOI: $10.7176 /$ RJFA/11-16-04

Publication date:August $31^{\text {st }} 2020$

\subsection{Introduction}

Board of directors are at the epicenter of the debate on effectiveness of corporate governance practices both in the public and private sector. The Cadbury report (1992) defined corporate governance as a system through which organizations are directed and controlled. Board of directors are charged both with roles of directing and controlling these entities. Tricker (1984) stated that boards of directors were responsible for developing strategic direction and monitoring performance. According to Shleifer and Vishny (1997) it is through corporate governance mechanisms including board structure that investors are guaranteed returns for their investments. Love (2011) observed that corporate governance mechanisms enhanced oversight leading to improved operating performance. In addition, it helped reduce risks and maximize value of investments by ensuring entities invested in profitable assets.

State owned enterprises (SOEs) play critical roles in both developed and developing countries. They are involved in provision of critical services including; education, health, water, in addition to economic growth. According to a World Bank report (2014) globally SOEs accounted for 20 percent of investments and six percent of employment. In addition, OECD (2015) stipulated that in the Middle East countries, SOEs accounted for 2050 percent of all investments. Collapse or underperformance of these SOEs could negatively impact these economies, leading to disruption of critical services, and become a fiscal burden. Due to their importance, attempts have been made by governments and other stakeholders to reform these SOEs to ensure that they are performing efficiently and effectively. The major areas of concern in these SOEs are accountability, transparency and performance. To address this challenges a number of countries have made attempts to reform these entities. These reforms have largely focused in improvement of corporate governance practices. The World Bank and Organization for Economic Co-operation and Development (OECD) have steered the development of sound corporate governance practices among the SOEs globally. The World Bank (2014) toolkit on corporate governance for state owned enterprises, reaffirms the importance of sound corporate governance principles to ensure efficiency and effectiveness in SOEs. Similarly, OECD (2015) on principles of corporate governance advocates for SOEs to operate in efficient and transparent manner. In Kenya the government developed Mwongozo (2015) code of corporate governance for state corporations. The code gives guidelines on how SOEs boards should be structured to ensure transparency, accountability and improved performance. This followed a presidential report (GoK, 2013) that highlighted challenges facing SOEs in Kenya including; poor performance, multiple competing objectives, budgetary constraints, political interference, and agency principal conflicts.

\subsection{Board Structure in State Owned Enterprises in Kenya}

In Kenya SOEs the board of directors are responsible and accountable for all corporate governance matters. Mwongozo (2015) code of governance for state corporations specifically guides how boards should be structured to achieve accountability and improved performance. On the subject of board size Mwongozo code recommends board membership of 7-9 members. Regarding board independence Mwongozo recommends that at least thirty percent of board members to be non-executive directors. The state corporation advisory committee (SCAC) is 
the body corporate tasked with roles of ensuring implementation of Mwongozo code. The committee is involved in training and assessing performance of state corporations' boards in Kenya based on Mwongozo guide. State corporation's boards of directors are also accountable to other stakeholders including; investors, line ministries and parliament through parliamentary committees. Based on this background it is predicted that sound corporate governance mechanisms could lead to improved performance and accountability in state owned entities. It is on this background that this study aims to examine the contribution of board structure as corporate governance mechanism towards improvement of SOEs performance in the commercial and manufacturing sector in Kenya. This study aims to address the following questions.

a. Does board size influence the performance SOEs in Kenya?

b. Does board independence influence the performance SOEs in Kenya?

c. Does firm size as control variable influence the relationship between board structure and performance SOEs in Kenya?

d. Does age since incorporation as control variable influence the relationship between board structure and performance in SOEs in Kenya?

\subsection{Literature Review}

\subsection{Theoretical Foundation}

The Agency theory as advanced by Jensen and Meckling (1979) states that agency problems arises as result of separation of ownership from control. This results to information asymmetry between the agent and the principal. Consequently, agency conflicts arise as the self-seeking agent may not always act on the best interest of the principal. Proponents of the agency theory argue that the agency conflicts could be resolved through corporate governance mechanisms. Bathala and Rao (1995) observed that non-executive directors offered monitoring roles thus helping to solve or mitigate the agency conflicts between management and shareholders. Kahle, Wang and $\mathrm{Wu}$ (2014) in support of agency theory argues for control of the self-seeking agent through board dominated by non- executive directors. Large boards are more effective in monitoring and controlling CEO compared to smaller boards. Kiel and Nicholson (2003) agreeing that large boards were more effective in controlling the agent thus reducing the agency conflicts.

In contrast to the agency theory, the stewardship theory holds that managers are naturally trustworthy hence they aim to protect and not exploit the shareholders interest (Donaldson \& Davis, 1991). The proponents of stewardship theory advise for more control for the steward to drive the organization to success. Proponents of stewardship theory advocates for governance structures that empower the steward as opposed to control. Smaller board as opposed to large board are preferred. Insider dominated boards as opposed to independent board preferred (Muth \& Donaldson ,1998).

The stakeholder's theory (Freeman, 1984) offers another perspective on board structure. The theory holds that boards of directors are important in managing the interests of competing stakeholders. Based on this theory boards should have representation of diverse stakeholders. Boards of directors should also help identify the diverse objectives of stakeholders and help to manage them (Donaldson \& Preston, 1995). This study aims to examine the effect of board structure on firm performance in state owned enterprises in Kenya. Based on the theoretical review this study was premised in the agency perspective on corporate governance.

\subsection{Empirical Review}

\subsubsection{Board Size and Firm Performance}

Empirical literature reviewed indicates a number studies examined the effect of board size on firm performance. The findings from both developed and developing economies were mixed and inconclusive. Based on previous studies board Size was operationalized as the total numbers of board membership (Saha \& Kabra, 2019; Oba, Tigrel, \& Sener, 2014).

Saha and Kabra (2019) studied the impact of corporate governance on firm performance in India. The study sampled 100 firms listed in Bombay Securties Exchange covering the period 2014-2018. Data was analyzed using regression analysis. The study established positive and significant relatiosnhip between board size and firm performance in India. The results suggesting large boards were more effective in monitoring management leading to improved performance.

Balagobei (2018) in a study in Sri Lanka examined the relationship between corporate governance and firm performance. The study obtained and tested data from listed firms from Sri Lanka covering the period 2010-2015. The study established that board size had a negative and significant effect on return on assets as a measure of performance. This suggested that smaller boards were more efficient in ensuring better performance in Sri lanka.

Ghabayen, Jaradat, Hardan and Al-Shbail (2018) in a study in Jordanian banking sector examined the effect of board size on firm performance. Using panel data regression analysis, the study tested the relationships between the variables covering the period 2004 to 2013. The study established insignificant relationship between 
board size and firm performance. Further, the study concluded that optimal board size was between 9 and 12 members. The study concluded too large or too small boards were ineffective in improving firm performance.

Kalsie and Shrivastav (2016) examined the effect of board size on firm performance of firms listed at NSE India covering the period 2008 to 2012. To investigate the relationship between the variables the study employed panel generalised least square, fixed and random models.The study conluded that board size was positively and signifcantly related to firm perfromance in India.

Fauzi and Locke (2012) examined the effect of board size on firms performance using data from listed companies in New zealand covering the period 2009 to 2012. Data was analyzed using the generalized equation model.The study concluded that large board were more effective in monitoring roles and improved firm performance significantly in New Zealand listed firms.

Topak (2011) examined the effect of board size on firm performance in Turkey. The study sampled data from 122 listed companies covering period of 2004 to 2009. To draw conlusion the study employed panel data regression. The study established insignificant effect of board size on firm performance in Turkey.

Emeka-Nwokeji and Agubata (2019) in a study in Nigeria tested the effect of board size on performance using data from non-financial firms listed in Nigeria securities exchange. The study established positive and significant effect of board size on firms' performance in Nigeria. This means that large boards significantly improved firm performance.

Heo (2018) in a study in Korea examined the effect of corporate governance on firm performance of state ownned enterprises. The study established positive and signficant effect of board size on performance in SOEs. The results suggested that large boards were more effective and transparent resulting to impoved performance of SOEs in Korea.

\subsubsection{Board Independence and Firm performance}

Agency theory predicts that independent boards will help monitor management leading to confidence among investors leading to improved performance. However empirical evidence on the relationship is inconclusive. Based on previous studies board independence was measured as percentage of non-executive directors in the board (Saha \& Kabra ,2019; Nath, Islam \& Saha, 2015).

Khan, Al-Jabri and Saif (2019) examined the association between board structure and corporate financial performance in Malaysia. To establish the nature of relationship the study adopted a dynamic panel model. The study established positive and significant relationship between board independence and firm performance in Malaysia.

Rashid (2018) examined the influence of board independence on firm economic performance of listed firms in Bangladesh. The study established the effect of board independence on economic performance was insignificant. However, the study established association between board size and economic performance was positive and significant.

Liu, Miletkov, Wei and Yang (2015) examined the effect of board independence on firm performance in China. Data was analyzed using generalized regression technique. The study established positive and significant effect of board independence on firm performance. The study further established that board independence was stronger in government controlled enterprises. This study confirmed that independent directors constrained insider dealing which boosted investor confidence resulting to improved performance.

Nath, Islam and Saha (2015) examined the relationship between board structure and firm performance in pharmaceutical companies in Bangladesh. The study established that the relatioship between board independence and firm performance was insignificant Dhaka securities exchange.

Niki, Setiany, Haryono, Suhardjanto and Nurharjanto (2018) investigated the effect of corporate governance mechanisms on firm performance before and after privatisation using SOEs in Indonesia. The study used mixed methods combining both primary and secondary data. The results revealed that corporate governance index was positively related to firm performannce.

Malik ( 2012) examined the effect of board independence on share prices using data from Karachi securities exchange 30 share index. The study covered a period of two years between 2009 and 2010. The study established the relationship between board independence and share prices was insignificant in Karachi securities exchange.

\subsection{Conceptual Framework}

Based on that based on agency theoretical framework and empirical evidence this study conceptualized a relationship between corporate governance variables including; board size, board independence and firm performance as presented in figure below. 


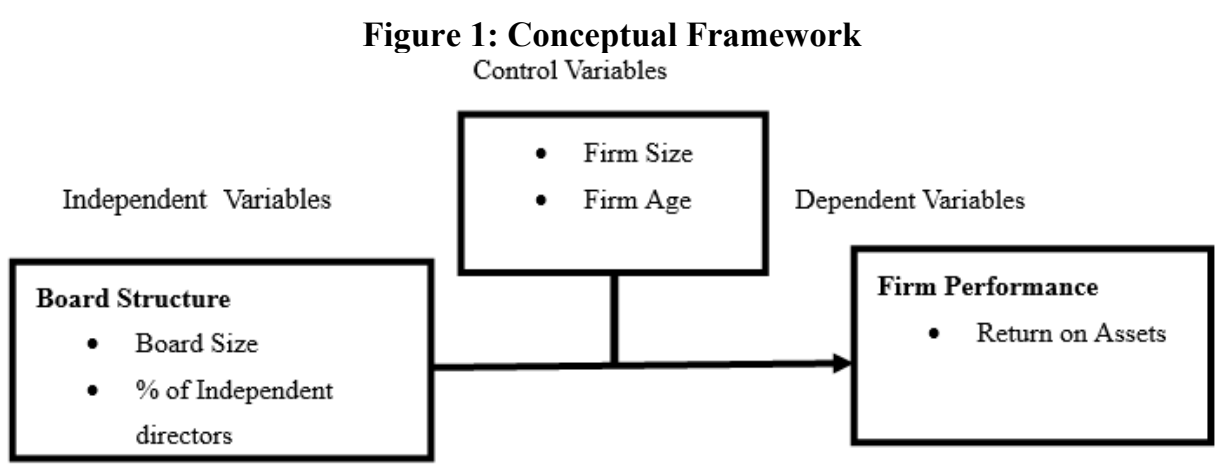

\subsection{Methodology}

\subsection{Research Design.}

This study takes a correlational study approach by examining the relationship among the research variables. Correlational study aims to test the significance and direction of relationship between variables. This information provides insights and is useful in making future predictions about phenomenon (Leedy \& Ormrod, 2010).

\subsection{Data collection}

The study collected data from secondary sources; derived from annual reports. The annual reports were obtained from Twenty-five (25) of the thirty-three (33) SOEs in commercial and manufacturing sector as categorized by state advisory committee (SCAC, 2020). The study covered a period of three years 2014 to 2016. Return on assets (ROA) was used as proxy of firm performance; the measure was computed using financial data obtained from financial statements in the annual reports. Data on board size and board independence was obtained from governance reports in the annual reports. Data on Firm age and form size as control variables was computed using information from annual reports.

\subsection{Study Hypothesis}

$\mathrm{H}_{1}$ : Board size positively and significantly influenced firm performance SOEs in Kenya.

$\mathrm{H}_{2:}$ Board independence positively and significantly influenced firm performance in SOEs in Kenya.

$\mathrm{H}_{3}$ : Firm size as control variable significantly influenced the relationship between board structures and firm performance in SOEs in Kenya.

$\mathrm{H}_{4}$ : Firm age as control variable significantly influenced the relationship between board structure and firm performance in SOEs in Kenya.

\subsection{Model Specification}

To examine the relationship between the variables the study employed panel data regression model with random and fixed effects.

Firm Performance $(\mathrm{ROA})=\beta_{0}+\beta_{1}$ BdSize $+\beta_{2}$ PerIND $+\beta_{3}$ Firm Size $+\beta_{4}$ Age $+\varepsilon$

Where:

$\mathrm{ROA}=$ Return on assets as measure of firm performance.

BDsize $=$ Board Size a measure of corporate governance

PerIND $=$ The percentage of independent directors.

$\beta_{0}$ the intercept

$\varepsilon$ the error term

\section{Dependent Variable}

The return on assets (ROA) as a measure of performance was used as the dependent variable. The value was operationalized as ratio of net income to total assets. Return on assets (ROA) ratio examined how well the entities utilizes assets to generate revenues and profits. This makes the ratio to be useful to investors and management in decision making (Warrad, 2015).

\section{Independent Variables}

Board size and Board independence were conceptualized to have effect on firm performance. This was based on theoretical framework and empirical studies evidence that suggested that large boards, and independent boards were effective in monitoring management leading to improved performance (Malik,2012; Liu, Miletkov, Wei \& Yang ,2015; Rashid, 2018).

\section{Control Variables}

The age since incorporation and firm size acted as control variables. This was based on evidence from previous studies that suggested that the size of the firm and age influenced the level of development in corporate 
governance. Large firms were predicted to have functional governance systems when compared to smaller firms.

Table 1: Operationalization of Study Variables.

\begin{tabular}{ll}
\hline Variable & Measure \\
\hline Independent Variables & \\
Board size & Measured as a number of board members \\
Board independence & Measured as percentage of non-executive directors \\
Dependent Variable & Return of assets ratio as proxy for firm performance.
\end{tabular}

Firm performance

Control Variables

Firm size

Age

Measured as logarithm of total assets

Measured as age of firm since incorporation

\subsection{Results and Discussion}

4.1 Descriptive Statistics

Table 2: Descriptive Statistics

\begin{tabular}{llcccc}
\hline Variable & Obs & Mean & Std .Dev & Min & Max \\
\hline Bsize & 75 & 10.08 & 10.08 & 4 & 16 \\
PerIND & 75 & .418 & .193 & 0 & .818 \\
AGE Firm & 75 & 37.08 & 20.704 & 6 & 94 \\
ROA & 75 & -.0150 & .1600 & -.7624 & .378 \\
\hline
\end{tabular}

Table 2 presents the descriptive statistics results for the study variables. The results show board size for SOEs had a mean size of 10.08 members with minimum of 4 members and a maximum of 16 members. This mean board size is above the recommended board size by the Mwongozo code of corporate governance size of 7 to 9 members. In addition, the results indicate the percentage of independent directors had a mean of $41.8 \%$ percentage and a maximum of $81.8 \%$ percentage. The mean of $41.8 \%$ is above the minimum percentage recommended by Mwongozo code of corporate governance recommends of at least thirty percent of board membership to be independent directors. The results indicate age since incorporation had mean of 37 years with a minimum age of six years. The results on ROA as measure of performance indicates mean $-1.5 \%$ with a maximum ROA of $37.84 \%$ but with a minimum of $-76.25 \%$. A negative mean ROA means that majority of SOEs were loss making.

\subsection{Pearson Correlation}

Table 3: Pearson Correlation.

\begin{tabular}{llllll}
\hline & \multicolumn{1}{c}{ ROA } & \multicolumn{1}{c}{ Bsize } & \multicolumn{1}{c}{ PerIND } & LOGTA & LOGAGE \\
\hline ROA & 1 & & & & \\
Bsize & $0.2798^{*}$ & 1 & & & \\
PerIND & -0.1643 & $-0.2561^{*}$ & 1 & & \\
LOGTA & 0.2139 & 0.1079 & $0.4994^{*}$ & 1 & \\
LOGAGE & 0.1469 & $-0.3505^{*}$ & $0.3002^{*}$ & 0.1888 & 1 \\
\hline
\end{tabular}

Note: Notes: Bsize =board size, PerIND =percentage of independent directors, Log TA $=$ firm size, LogAGE $=$ age since incorporation

The Pearson correlation measures the relationship between the variables and the strength of the association. Table 3 presents the Pearson correlation results between the study variables. The results show positive correlation $(\mathrm{r}=0.279)$ between board size and ROA statistically significant. Further, the results show board independence had a negative correlation with ROA $(\mathrm{r}=-0.1643)$. In addition, the results indicate ROA had a positive correlation $(\mathrm{r}=0.2139)$ with firm size. Board Size had a negative correlation with age since incorporation that was statistically significant $(\mathrm{r}=-0.3505)$. Board independence had a positive correlation $(r=0.3002)$ with age of firm since incorporation.

\subsection{Diagnostics Tests}

\subsubsection{Multi- Collinearity Test}

Multi-Collinearity problems occurs when there exists high correlation among the explanatory variables. This will interfere with the interpretation of regression outputs. As result, absence of multicollinearity is a key assumption for regression results to be dependable. Table 6 presents the multicollinearity statistics. The results reveal VIF values of below $<10$. This means multicollinearity problem was not significant. This means the regression results obtained are dependable. 
Table 4: Collinearity statistics

\begin{tabular}{lcc}
\hline & Tolerance & VIF \\
\hline Bsize & .221 & 4.521 \\
PerIND & .230 & 4.343 \\
LogTA & .894 & 1.119 \\
LogAge & .817 & 1.224 \\
\hline
\end{tabular}

\section{a Dependent Variable: ROA}

\subsubsection{Heteroscedasticity test}

The Breusch - pagan test was used to test for heteroscedacity problem. This problem occurs when there exists variance in the error term. Heteroscedacity is a key assumption for the results of regression to be consistent. The Breusch pagan test results show Chi- square value of 20.26 with $\mathrm{p}=$ value of $0.0004<0.05$ statistically significant to reject the null hypothesis, that variances for explanatory variables were constant. This means heteroscedasticity problem was not significant as the variances among the explanatory variables were not constant.

Table 5: Breusch-Pagan test Results

\begin{tabular}{|l|l|}
\hline chi2(4) & $=20.26$ \\
\hline Prob $>$ chi2 & $=0.0004$ \\
\hline
\end{tabular}

Ho: Constant variance

4.3.3 Hausman Test

Table 6: Hausman Test Results

\begin{tabular}{|l|l|l|l|l|}
\hline & fixed $(\mathrm{b})$ & fixed $(\mathrm{B})$ & Difference $(\mathrm{b}-\mathrm{B})$ & SE \\
\hline Bsize & .0014847 & .0110162 & -.0095316 & .0136229 \\
\hline PerIND & -.1070371 & -.1448559 & .0378188 & .1869311 \\
\hline LOGTA & .1081519 & .0269776 & .0811743 & .0538084 \\
\hline LOGAGE & -.5003987 & .0411667 & -.5415654 & .279784 \\
\hline
\end{tabular}

$\mathrm{H}_{\mathrm{o}}$ : Random effect

$\mathrm{H}_{1}$ : Fixed effect

$\mathrm{b}=$ consistent under Ho and Ha; obtained from xtreg B = inconsistent under Ha, efficient under Ho; obtained from xtreg Test: Ho: difference in coefficients not systematic.

$$
\operatorname{ch} 2(4)=9.34 \quad \text { Prob }>\text { chi } 2=0.0532
$$

Table 6 presents Hausman tests results. The Hausman test was used to differentiate random and fixed effects in regression analysis. The results show $\mathrm{p}$ value of $0.0532>0.05$ that is statistically insignificant. The null hypothesis $\mathrm{H}_{0}$ is that the random effect model was appropriate. This means the null hypothesis was not rejected. The random model was therefore preferred to the fixed effect model.

\subsection{Regression Results.}

4.4.1 Regression Results Summary

Table 7: Regression Results Summary

\begin{tabular}{lr}
\hline Prob $>$ F & 0.0009 \\
R-squared & 0.2326 \\
Adj R-squared & 0.1887 \\
Root MSE & 0.1441
\end{tabular}

Table 7 presents summary output of regression results of board structure on firm performance. The results reveal $\mathrm{R}$ squared value of 0.1886 statistically significant with $\mathrm{p}$ value $<0.05$. This means that $18.8 \%$ changes in the response variable could be explained by the explanatory variable. This finding reveals that corporate governance variables including the board size and board independence significantly contributed to firm performance of SOEs in Kenya as measured by return on assets.

4.4.2 Effect of Board Structure on Firm Performance.

Table 8: Regression Results

\begin{tabular}{lllllll}
\hline ROA & Coef. & Std. Err & $\mathrm{t}$ & $\mathrm{P}>|\mathrm{t}|$ & {$[95 \%$ Conf. Interval] } \\
\hline Bsize & .020825 & .0094887 & 2.19 & 0.032 & .0019004 & .039749 \\
PerIND & -.2730657 & .107876 & -2.53 & 0.014 & -.4882175 & -.057913 \\
LOGTA & .0271655 & .0116209 & 2.34 & 0.022 & .0039884 & .050342 \\
LOGAGE & .0744558 & .0306973 & 2.43 & 0.018 & .0132319 & .135679 \\
Cons & -1.000274 & .2587453 & -3.87 & 0.018 & -1.516325 & -.484222 \\
\hline
\end{tabular}

a. Dependent Variable: ROA

Table 8 presents regression results of board structure on firm performance. The results indicate that board 
size had a positive relationship with firm performance with positive coefficient $\beta 0.0208$ which was statistically significant with $\mathrm{p}$ value $<0.05$. This suggest that unit increase in board size increased firm performance. This means that large boards increased board monitoring resulting to improved performance.

The results on board independence show a negative relationship with firm performance with negative coefficient value $\beta-0.2730$ statistically significant with $p$ value $<0.05$. The results suggest that increase in the percentage of independent directors had a negative effect on firm performance in SOEs in Kenya. This means board independence did not lead to improved performance.

The results on the effect of firm size on firm performance measured by logarithm of total assets had positive and significant effect on firm performance, with positive coefficient value $\beta 0.0271655$. Age since incorporation as control variable also had positive effect on the relationship with firm performance with positive coefficient value $\beta 0.0744$ also statistically significant $p$ value $<0.05$. This means both firm size and age of firm as control variables contributed significantly to the relationship between board structure and firm performance.

\subsection{Conclusion and Recommendations}

The study examined the effect of board structure on firm performance in the state owned entities in commercial and manufacturing sector in Kenya. The results revealed significant positive effect of board size on firm performance in commercial and manufacturing SOEs in Kenya. This suggests that large boards contributed significantly to improved performance in SOEs in Kenya. This results are justified in the Agency theoretical framework that predicts that larger board are effective in monitoring management resulting to improved performance. This finding also in agreement with other previous studies (Saha \& Kabra, 2019; Kalsie \& Shrivastav, 2016; Fauzi \& Locke, 2012.

The results on the effect of board independence on firm performance established negative and significant effect on firm performance. This finding is not in consistent with agency theory perspective that predicts that independent boards will lead to improved monitoring function resulting to improved performance (Khan, AlJabri \& Saif, 2019; Rashid, 2018). This mean that independent directors negatively influenced the performance of commercial and manufacturing SOEs in Kenya. This suggest that higher percentage of independent directors had a negative effect on firm performance. This also suggest that the inclusion of independent SOEs board was not necessary to improve performance. Independent directors maybe lacking information about the entity operations hence thus making minimal contribution towards performance improvement. The findings are in agreement with other previous studies that established that the higher proportion of independent directors negatively related to firm performance (Saha \& Kabra, 2019; Nath, Islam \& Saha ,2015; Malik \&2012).

Finally, the study established positive and significant effect of control variables of firm size and age of firm since incorporation on firm performance. The findings on the effect of control variables suggest that large firms and those that had been existent for long periods had established strong governance structures resulting to improved performance. This study finding contributes to corporate governance literature in the public where comparatively it is limited due to minimal studies in the public sector context. The study findings will be useful in guiding decision and policy on how to improve corporate governance practices and performance in state owned enterprises in Kenya. Future studies should consider addressing other aspects of corporate governance not addressed in this study including gender and board expertise.

\section{References}

Balagobei, S. (2018). Corporate Governance and Firm Performance: Empirical Evidence from Emerging Market. Asian Economic and Financial Review, Asian Economic and Social Society, 8(12), 1415-1421.

Bathala, C. T., \& Rao, R. P. (1995). Determinants of board composition: An agency theory perspective. Managerial decision economics, 16, 59-69.

Committee on the Financial Aspects of Corporate Governance., \& Cadbury, A. (1992). Report of the Committee on the Financial Aspects of Corporate Governance. London: Gee.

Donaldson, L., \& Davis, J. (1991). Stewardship theory or Agency theory: CEO governance and shareholder returns. Australian Journal of Management, 16(1), 49-64. Retrieved from http://dx.doi.org/10.1177/031289629101600103

Donaldson, T., \& Preston, L. E. (1995). The stakeholder theory of the corporation: concepts, evidence, and implications. Academy of Managerial Review, 20(1), 65-91.

Fauzi, F., \& Locke, S. (2012). Board structure, ownnership structures and firm performance: A study of New Zealand Listed firms. Asian Academy of management Journal of accounting and Finance, 8(2), 43-67.

Freeman, R. (1984). Strategic Management: A Stakeholder Approach. London: Pitman.

Emeka-Nwokeji, N. A., \& Agubata, S. N. (2019). Board Attributes and Corporate Performance: Evidence from Nonfinancial Firms in Nigeria. Journal of Economics and Business, 2(2), 205-217. doi:0.31014/aior.1992.02.02.80

Ghabayen, M. A., Jaradat, Z., Hardan, A., \& Al-Shbail, M. O. (2018). Optimal board size in the Jordanian banks: 
Empirical evidence based on accounting performance. Journal of Business and Retail Management Research, 13(1), 219-227.

Government of Kenya . (2013). Report of The Presidential Taskforce on Parastatal Reforms . Nairobi: Government of Kenya.

Heo, K. (2018, August 16). Effects of Corporate Governance on the Performance of State-Owned Enterprises. World Bank Research Policy Paper No: 8555.

Jakpar, S., Tinggi, M., \& hui, T. K. (2019). Analysis of Corporate Governance and Firm Performance: Evidence from Malaysian Listed Companies. International Journal of Business and Social Science, 10(1), 118-133.

Jensen, M. C., \& Meckling, W. (1976). Theory of the firm: Managerial behaviour,agency costs and ownership structure. Journal of Financial Economics, 3(4), 305-360.

Kahle, M., Wang, L., \& Wu, J. (2014). Board structure: an empirical study of firms in Anglo-American governance environments. Managerial Finance, 40(7), 681 - 699.

Kalsie, A., \& Shrivastav, S. M. (2016). Analysis of Board Size and Firm Performance: Evidence from NSE Companies Using Panel Data Approach. Companies Using Panel Data Approach, 9(2), 148-172. Retrieved from https://doi.org/10.1177/0974686216666456

Kiel,, G. C., \& Nicholson, G. J. (2003). Board composition and Corporate performance: How the Australian experience inform scontrasting theories of corporate governance. Corporate Governance: An International Review, 11(3), 189-205.

Khan, M. T., Al-Jabri, Q. M., \& Saif, N. (2019). Dynamic relationship between corporate board structure and firm performance: Evidence from Malaysia. International Journal of Finance \& Economics. Retrieved from https://doi.org/10.1002/ijfe. 1808

Leedy, P. D., \& Ormrod, J. E. (2010). Practical Research: Planning and Design. Boston: Pearson Educational International.

Liu, Y., Miletkov, M. K., Wei, Z., \& Yang, T. (2015). Board independence and firm performance in China. Journal of Corporate Finance, 30, 223-244. Retrieved from https://doi.org/10.1016/j.jcorpfin.2014.12.004

Love, I. (2011). Corporate Governance and Performance around the World: What We Know and What We Don't. World Bank Research Observer, 26(1), 42-70.

Malik, S. U. (2012). Relationship between Corporate Governance Score and Stock Prices: Evidence from KSE30 Index Companies. International Journal of Business and Social Science, 3(4), 239-249.

Muth, M. M., \& Donaldson , L. (1998). Stewardship Theory and Board Structure: a contingency approach. Scholarly Research and Theory Papers, 6(1), 5-28.

Nath, S. D., Islam, S., \& Saha, A. K. (2015). Corporate Board Structure and Firm Performance: The Context of Pharmaceutical Industry in Bangladesh. International Journal of Economics and Finance, 7(7), 106-115.

Niki, L., Setiany, E., Haryono, T., Suhardjanto, D., \& Nurharjanto. (2018). Corporate governance, Privatisation, performance of Indonnesian state owned enterprises. International Journal of Revenue Management, 166188.

Oba, B., Tigrel, E., \& Sener, P. (2014). Board structure in listed firms: evidence from an emerging economy. Corporate Governance, 14(3), 382 - 394. doi:http://dx.doi.org/10.1108/CG-05-2012-0044

OECD. (2015). OECD Guidelines on Corporate Governance of State-Owned Enterprises. Paris: OECD Publications.

Donaldson, T., \& Preston, L. E. (1995). The stakeholder theory of the corporation: concepts, evidence, and implications. Academy of Managerial Review, 20(1), 65-91.

Rashid, A. (2018). Board independenceand firm performance:Evidencefrom Bangladesh. Future Business Journal, 4, 34-49.

Saha, R., \& Kabra, K. C. (2019). Does corporate governance influence firm performance?Evidence from India. Economics and Business Review, 5(19). doi:10.18559/ebr.2019.4.4

Shleifer, A., \& Vishny, R. W. (1997). A Survey of Corporate Governance. The Journal of Finance, 2, $737-783$.

Topak, M. S. (2011). The Effect of Board Size on Firm Performance:Evidence from Turkey. Middle Eastern Finance and Economics(14), 120-127.

Tricker, R. I. (1984). Corporate governance: Practices, procedures and power in British companies and their boards of directors. London: Glover Press.

Warrad, L. (2015). Return on Asset and Return on Equity Effects of Net Operating Cycle: Jordanian Study. Research Journal of Finance and Accounting, 6(14), 89-95.

World Bank. (2014). Corporate governance of state-owned enterprises: A Toolkit. Washington, DC: World Bank. 